\title{
The Implementation of Teaching Supervision in Excellence Cluster Secondary Schools and Daily Secondary Schools
}

\author{
Azrani Mohd Zain \\ Department of Foundation of Education, Faculty of Educational Studies \\ Universiti Putra Malaysia, 43400 UPM Serdang, Selangor, Malaysia \\ Soaib Asimiran* (Corresponding Author) \\ Department of Foundation of Education, Faculty of Educational Studies \\ Universiti Putra Malaysia, 43400 UPM Serdang, Selangor, Malaysia
}

\begin{abstract}
Abu Bakar Razali
Department of Language and Humanities Education, Faculty of Educational Studies Universiti Putra Malaysia, 43400 UPM Serdang, Selangor, Malaysia
\end{abstract}

Nor Aniza Ahmad

Department of Foundation of Education, Faculty of Educational Studies

Universiti Putra Malaysia, 43400 UPM Serdang, Selangor, Malaysia

Received: Oct. 5, $2021 \quad$ Accepted: Nov. 15, 2021 Online published: Nov. 25, 2021

doi:10.5296/ijhrs.v11i4S.19251ＵRL: https://doi.org/10.5296/ijhrs.v11i4S.19251

\begin{abstract}
This study explores the implementation of teaching supervision in Excellence Cluster National Secondary Schools and Daily Secondary Schools. This study adopts the qualitative exploratory approach and involves eight study samples selected by purposive sampling. Methods of interview, observation and document analysis were used as the main tools in collecting the study data. The data collected were analysed using in-depth reading, open
\end{abstract}


coding and axial coding. The results of the study as a whole show that the two categories of schools do not show differences in the characteristics studied in the implementation of teaching supervision in secondary schools. The study's findings show that teaching supervision in Excellence Cluster Secondary Schools and Daily Secondary Schools is implemented through the devolution of power to middle leaders. Teaching supervision is guided by the teaching supervision form found in SKPMG2 standard 4. Teaching supervision in both school categories is done three times a year involving three phases. Moreover, teaching evaluation is done through direct observation in the classroom with full guidance on the teaching supervision form. The similarity in the implementation of teaching supervision is due to the same challenges faced by principals in both school categories, namely time constraints and administrative workload. The findings also show that supervisors use no specific approach for teaching supervision. The implication of this study is that it provides an insight into the implementation of teaching supervision by school administrators and that strengthening the skills and knowledge of middle leaders could improve teaching supervision effectiveness and positively impact the students, teachers and the school.

Keywords: teaching supervision implementation, middle leaders, teaching supervision practices

\section{Introduction}

\subsection{Quality of Teaching}

The quality of teaching could be assessed through students' ability to acquire the content knowledge during a lesson. Quality teachers are aware of their ability and constantly improve their communication skills, curriculum understanding, diversify delivery methods, and increase their pedagogical mastery (Douglas B. Reeves, 2020). Furthermore, school administrators should conduct evaluations to identify teachers' weaknesses and strengths. Therefore, teaching supervision is a mechanism that is seen to be appropriate in helping, guiding and improving the quality of teaching and further developing the professionalism of teachers. Teaching supervision is also seen as a measuring tool to determine whether teachers can deliver the curriculum as prescribed. Effective teaching supervision implementation will help increase teaching quality through supervisors' guidance and sharing of expertise. The success of teaching supervision is associated with the effectiveness of the leadership style adopted by school administrators, especially principals as instructional leaders. The practice of teaching supervision also plays a role in determining the effectiveness of teaching supervision implemented. In this study, teaching supervision practices refer to the supervisors' approach while performing teaching supervision in the classroom. Supervisors can apply various approaches to teaching supervision; however, in this study, the discussion is directed towards clinical supervision approaches. The clinical supervision approach is effective in helping to improve the quality of teaching and develop teacher professionalism.

\subsection{Problem Statement}

Teaching supervision is the sole responsibility of the principal. However, as the highest-ranked administrator in the school, principals often face time constraints and 
administrative workload. These factors have hindered principals from conducting teaching supervision as prescribed (Ahmad Kamal, 2016). At the same time, the implementation of teaching supervision requires in-depth expertise and knowledge related to the field. However, the teaching supervision implemented for the time being does not help solve problems in the teaching because the supervisors responsible for supervising teaching are not skilled in the subjects supervised (Chien-Chin Chen, 2018). This situation also contributes to the misconception of teachers on the function of teaching supervision as they assume teaching supervision does not contribute to teacher development. In this light, the lack of supervision skills and lack of exposure to the appropriate teaching supervision practices are among the factors that contribute to failure in implementing teaching supervision effectively (Shukri Zain, 2011). This situation is evident in some schools when the newly appointed department heads supervise other teachers.

Excellence Cluster Secondary Schools are schools that show excellence in their clusters, particularly in management and student development. The establishment of Excellence Cluster Secondary Schools aims to enhance the excellence of the Malaysian education system. These schools become the benchmark and role models for other schools within and outside the cluster. Meanwhile, Daily Secondary Schools were established to provide equal educational opportunities to all Malaysians. Generally, students in Excellence Cluster Secondary Schools show higher academic achievement than students in Daily Secondary Schools. Examining the implementation of teaching supervision in both schools is necessary to identify a difference between teaching supervision practices in both schools and whether these practices contribute to students' academic achievement from both school categories. This study examines the implementation of teaching supervision and explores supervisory practices in Excellence Cluster Secondary Schools and Daily Secondary Schools. The selection of two different school categories allows data triangulation from different school categories to achieve data saturation between these two research contexts. The case study was conducted in two school categories based on these characteristics to obtain rich data and inputs for comparison.

\subsection{Research Questions}

Two research questions were developed for this research.

i. What is the form of teaching supervision practices adopted in Excellence Cluster Secondary Schools and Daily Secondary Schools?

ii. What is the teaching supervision approach being applied in Cluster of Excellence National High School and Daily National High School?

\section{Literature Review}

The discussion in this section focuses on teaching supervision, implementation of teaching supervision in schools, and teaching supervision practices. Each aspect will be discussed in detail below: 


\subsection{The Concept of Teaching Supervision}

During teaching supervision, the supervisor is responsible for supporting and guiding teachers in carrying out their teaching and daily tasks more effectively. Teaching supervision is a collaborative effort between supervisors and teachers to improve teaching performance and quality without focusing on teachers' weaknesses (Glickman \& Ross-Gordon, 2017). Systematic and interesting teaching methods and good content delivery style could ensure good understanding and mastery of learning. In this light, teachers are the driving force in implementing the MOE's curriculum and achieving the national education philosophy. In the meantime, school principals as administrators must ensure that the curriculum is delivered successfully. Based on these needs, school administrators, especially the principal, need to monitor and supervise teaching through teaching supervision to ensure that the prescribed curriculum is delivered and implemented in the classroom.

Teaching supervision provides a tool for principals to gain insights into real classroom scenarios (Gordon, 2020). Through this approach, principals can monitor specifically the teaching and learning process performed by teachers. This situation gives the principal the advantage of finding weaknesses that need improvements and strengthening teachers' good practices (Honig \& Rainey, 2020). In addition, teaching supervision provides useful input to school administrators and provides positive input to teachers in improving their classroom practices to ensure that future lessons are more effective.

\subsection{The Implementation of Teaching Supervision}

The implementation of teaching supervision in schools is associated with the approaches adopted by school administrators. In this light, teaching supervision approaches refer to the specific structure and planning compiled by the school to ensure the smoothness of teaching supervision. In Malaysia, teaching supervision is based on MOE Professional Circular Letter No. 3/1987 (SPI). According to the SPI, the school management is required to supervise teachers' practices in the classroom. The goal of teaching supervision is to ensure that the curriculum delivery process in schools adheres to set standards.

Supervising teaching is a task that must be performed by principals as directed in the SPI. Principals are fully responsible for supervising the entire teaching of teachers in schools (Ministry of Education Malaysia, 2012). However, principals can delegate the authority for supervision to senior assistants as outlined in the SPI. This approach aims to balance the workload of principals who are in charge of administrative matters in the school. The findings of previous studies show that middle leaders in schools are responsible for supervising teaching. According to Khairuleffendi, Faiz and Hapini (2019), school principals have delegated the authority to middle-level leaders, specifically the Senior Administrative Assistant, Senior Student Affairs Assistant, senior co-curricular assistant, and field leaders and Head of Panel. Teachers will be assigned to specific middle-level leaders who will supervise their teaching according to a set schedule. In general, the findings from previous studies do not specifically discuss the form and method of implementation of teaching supervision conducted in Excellence Cluster Secondary Schools (SMKKK) compared to Daily Secondary Schools (SMKH). This situation raises the question of whether there are 
similarities or differences in the forms and methods of implementation of teaching supervision in SMKKK and SMKH. Therefore, this matter needs to be examined and studied to see what forms and methods of implementation of teaching supervision are practised in both categories of schools.

Principals often delegate responsibilities to supervise teaching to senior assistants and other middle leaders in schools to balance the workload and overcome the constraints that hinder them from fully implementing the supervision task (Mohammed Sani, 2013). In addition, this method has several advantages. For instance, the appointment of field leaders as teaching supervisors could streamline the supervisory process and increase its effectiveness (Shukri Zain, 2011). This is because field leaders will supervise teachers teaching the respective subject, allowing the supervisors to share expertise with them. The implementation of teaching supervision in schools is implemented three times a year and involves three phases based on the standard 4 SKPMG2 teaching supervision form (Md Said Daimon, 2019). Teaching will be evaluated based on the items in the instrument, and teachers will be scored according to the criteria. Assessment of teaching is made through direct observation of teaching in the classroom. Furthermore, there is no specific approach practised in teaching supervision.

Past studies showed that teaching supervision in Malaysia is mainly implemented by delegating authority to senior assistants, subject leaders, or middle leaders. This system helps ensure the implementation of teaching supervision in schools as instructed by the MOE. A study by Khairul Effendi, Faiz and Hapini (2019) claimed that principals do not supervise all teachers in schools due to time constraints and school administration workloads. As a result, supervising teachers has been delegated to senior assistants, field heads and heads of panel. A special schedule for supervising teachers has been established to facilitate the supervision of teachers. This method is seen to improve the efficiency of teaching supervision and balance the principal's school administration workloads (Zabidah, Azlin, Mohd Zabil Ikhsan, 2019). While past studies have shown that principals of Daily Secondary Schools delegate their supervision tasks to middle learners, there is no evidence of the adoption of this method in Excellence Cluster Secondary Schools.

\subsection{Teaching Supervision Practices}

The practice of teaching supervision is linked to the approaches used by supervisors when supervising teachers' teaching (Kathryn, Debbie \& Theresa, 2019). Choosing a suitable supervision approach is the key to the effectiveness of teaching supervision. This study focuses on the use of the clinical supervision approach in schools. The clinical supervision approach forms the basis for teaching supervision practices in this study. It focuses on supervision based on a framework of reference of a "treatment" to improve teaching practices or optimise teachers' teaching. Something needs to be improved in teaching. (Acheson \& Gall, 2014). The implementation of teaching supervision aims to improve the quality of teachers' teaching by providing support and assistance through planned activities. It is focused on overcoming teacher's shortcomings and weaknesses through an identification process during teachers' classroom observations. 


\section{Macrothink}

International Journal of Human Resource Studies

ISSN 2162-3058

2021, Vol. 11, No. 4 S

Clinical supervision requires supervisors to directly observe a teacher's teaching practices in the classroom, collect and obtain data from the observation process, and analyse teachers' behaviour and actions during the teaching and learning process to improve teaching quality. In general, there are five steps in clinical supervision, which are pre-observation conference, ii) observation, iii) analysis, iv) post-observation conference, and v) post-observation conference analysis. The clinical supervision approach is a practical teaching supervision practice to meet the real goals of supervision. Acheson and Gall (2014) stated that this model could develop teacher professionalism and help improve the quality of teaching delivered by teachers in the classroom.

The clinical supervision approach focuses on teachers' teaching techniques and does not focus directly on school management. A clinical supervision process begins with collecting concrete data and observing classroom teaching in the classroom rather than related to the theories that should be carried out to implement supervision (Elizabeth Holloway, 2016). Through the clinical supervision approach, teachers feel more comfortable and motivated to do better teaching and learning during the supervision process. The clinical supervision approach needs to be practised by leaders in both school categories because this approach can continuously improve the quality of teaching and professionalism of teachers.

It can be concluded that clinical supervision is a specially designed programme that provides equal opportunities for supervisors and teachers to discuss the issues identified during the observation process. The focus of the discussion is to provide insights and feedback on teachers' weaknesses and strengths observed. Then, principals and teachers would collaboratively optimise the identified strengths and find the best solution to the weaknesses in teaching. A study on teaching supervision approaches was conducted to examine the effectiveness of existing approaches applied by school leaders while supervising teaching. In addition, this study aims to analyse the strengths and weaknesses of the teaching supervision approach implemented and see whether the school uses other approaches for teaching supervision. In the end, this study examines whether the clinical supervision approach is an appropriate approach for teaching supervision. 


\subsection{Conceptual Framework for Research}

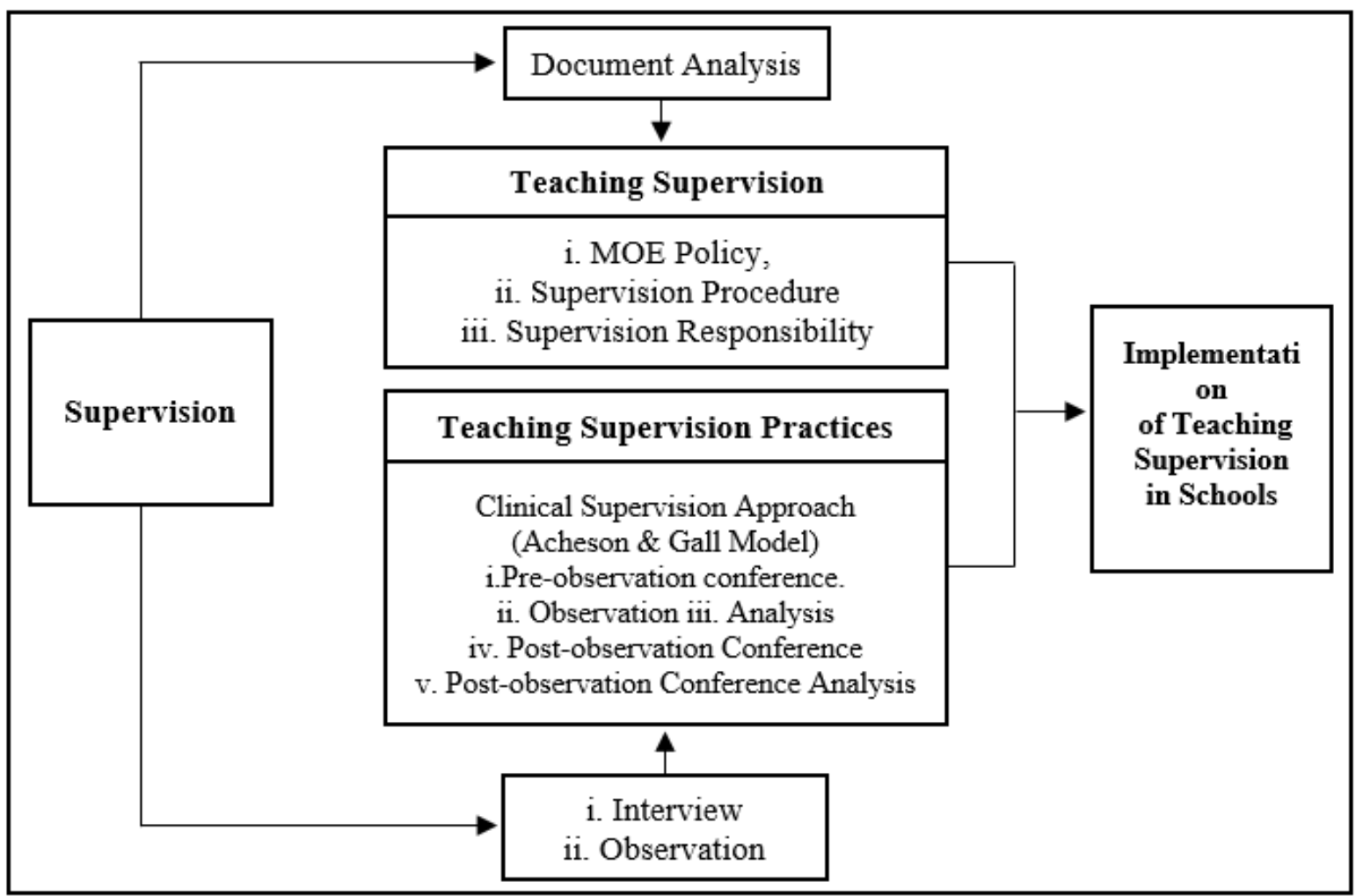

Figure 1. Conceptual Framework for Research

\section{Research Methodology}

This study is a qualitative study that adopts the case study method (multi-fields). The qualitative case study research design was chosen because this approach helps research explore, conclude, interpret, and translate the study's findings comprehensively (Creswell, 2020). For this study, the researcher has chosen the exploratory case study design using the holistic design. Marja Sarvimaki (2017) explained that a holistic design is a case study design that only takes one unit of analysis but can use one or more cases.

The data were collected in Excellence Cluster Secondary Schools (SMKKK) and Daily Secondary Schools (SMKH) in Kelantan. Eight participants selected through the purposive sampling method were involved in this study. Study participants consisted of school administrators directly involved in managing the implementation of teaching supervision in schools. The profiles of the study's participants are presented in Table 1. The data collected were analysed through in-depth reading, open coding and axial coding. The analysed data were sent back to the study participants for review and validation. Next, the data were given to three experts in the qualitative field for another round of review and validation. The Cohen Kappa index method was used to determine the validity value. The value obtained is 0.89 , exceeding the minimum of 0.60, as recommended by Wheelock et al. 2000 (Monique H, Inge Hutter \& Ajay Bailey, 2020). 
Table 1. Participants' Profile

\begin{tabular}{lclcccc}
\hline Code & Age & & Sex & \multicolumn{2}{c}{ Grade Position School Category } & School Location \\
\hline SK/ PPH 1 & 57 & Male & DG 54 & SMKKK & Kelantan & \\
SK/ PKP 2 & 56 & Female & DG 52 & SMKKK & Kelantan & \\
SK/ PKH 3 & 52 & Male & & DG 52 & SMKKK & Kelantan \\
SK/ PKK 4 & 50 & Male & DG 48 & SMKKK & Kelantan & \\
SH/ PPH 5 & 58 & Female & & DG 54 & SMKH & Kelantan \\
SH/ PKP 6 & 57 & Male & DG 52 & SMKH & Kelantan & \\
SH/ PKH 7 & 50 & Male & DG 48 & SMKH & Kelantan & \\
SH/ PKK 8 & 48 & Female & & DG 52 & SMKH & Kelantan \\
\hline
\end{tabular}

\section{Research Findings}

The discussion of the study's findings focuses on the main research questions. The first part focuses on answering the first research question, 'What is the form of teaching supervision implementation in Excellence Cluster Secondary Schools and Daily Secondary Schools' while the second part focuses on discussing, "What are the teaching supervision practices implemented in Excellence Cluster Secondary Schools and Daily Secondary Schools ?' The discussion of the study's findings is presented below.

4.1 What Is the Form of Teaching Supervision Implementation in Excellence Cluster Secondary Schools and Daily Secondary Schools'?

The Ministry of Education Malaysia has instructed schools to implement teaching supervision to ensure that the learning curriculum is implemented as prescribed through its SPI. Therefore, the school administrators have to supervise teaching three times a year through three phases. The first phase is from January to April, the second phase is from May to June, and the third phase is from August to December. Some study participants explained this,

"...all forms of supervision that occur in our schools fully follow the instructions from the $M O E$.. that is why it is a policy that has been set ... and applied by all schools .. for example, the instrument we use is guided by the SKPMG2 form through standard 4 .. ."

(SK/ PKH 3: 18)

“... we have created a supervisory calendar ... for the purpose and reference of administrators and teachers ... but the phases guide our calendar set out in SKPMG2 ... during that phase .. we will align the dates in accordance ..."

(SH/ PPH 5:28)

"... if we follow the sequence and guidelines in SKPMG2, teachers must be supervised three times ... and we have to follow the guidelines ... because each level must have a report..." 


\section{Ml Macrothink}

International Journal of Human Resource Studies

ISSN 2162-3058

2021, Vol. 11, No. 4S

The main goal of teaching supervision is to help improve the quality of teaching and develop teacher professionalism. Teaching supervision helps school administrators detect weaknesses in teaching and then collaboratively help address weaknesses to ensure the effective delivery of the curriculum. Teaching supervision is not intended to make assessments and find fault in teaching alone. However, teaching supervision is a mechanism that encourages cooperation and partnership between supervisors and teachers as they share their experience and expertise to generate ideas to address problems in the classroom. The study participants that supported these findings,

"... Yes .. the goal of teaching supervision is actually to see the extent of teaching that teachers implement ... so that teachers do not run away from the actual content ..."

(SK/PPH 1:4)

“... Sometimes it's like that ... teachers are afraid when they hear that the administrator wants to supervise their teaching ... we don't really want to find fault ... if we want to help what is right ... we want to share how to teach ... sometimes they are great at teaching ... we as administrators take knowledge from them ..."

(SH/ PKP 6:40)

The implementation of teaching supervision also involves adherence to certain procedures. Supervision of teaching in schools is implemented following the procedures set out in the standard SKPMG2 supervision form no. 4. The form includes six evaluation criteria that must be observed during the supervision. The teacher's teaching is evaluated based on the scores stated in the supervision form. The scores will then be summed to get the overall marks. This discussion is in line with the study participants as follows:

"... We at the school follow the guidelines in the SKPMG2 form ... the entire teaching of teachers will be evaluated based on the criteria in the form ..."

(SK/ PKP 2: 13)

“... Speaking of this procedure ... As supervisors, we follow the supervision form provided to us ... everything is complete ... teachers will be evaluated based on the form ..."

(SH/ PKH 7:46)

The MOE SPI outlines that teaching supervision is the responsibility of the principal. However, principals have delegated the task to middle leaders due to time constraints and the workload of managing administrative affairs in schools. This aims to coordinate and ensure that teachers are supervised according to set criteria and on schedule. The middle leaders involved are senior administrative assistants, senior assistants for student affairs, senior co-curricular assistants and field leaders, as described by the study participants through the following statements:

“... All administrators in the school are involved in supervising teaching ... I ask that the task of supervising be divided among all administrators ..." 
(SH/ PKP 6:41)

"... If you follow the circular, it is the principal's responsibility ..., but there is flexibility if I want to supervise the teaching teacher ... The answer is I didn't have time ... so this principal has to manage the whole school. Everything has to be taken care of ... so other administrators are also involved ..."

(SK/ PKK 4: 22)

The delegation of supervising authority to field leaders has caused teachers' misconceptions about supervisors' quality and capabilities. In this regard, newly appointed field leaders seem to lack experience in administration and expertise in related subjects. The study participants explained this situation,

"... Maybe there is a bit of an error there ... I don't deny it, the head of the field who just took office still lacks experience ... especially in terms of administration ... but this is the platform for him to learn ... First of all, all administrators are like that... I also started from there ..."

(SK/ PPH 1: 7)

“... For me there is no problem ... because even though I am new as a field leader .. but they are the old and experienced teachers ... there are subjects that they are good at ... especially the ones they teach .. only some subjects they do not teach .. under each field head many subjects are taken care of ..."

(SH/ PKK 8:58)

The implementation of teaching supervision can help teachers deal with problems during teaching and learning in the classroom. The excellence of students' academic achievement does not lie in the existing qualities of students alone. However, guidance from middle learners is paramount for effective teaching and the delivery of lesson content. Teachers who are effective in teaching can produce excellent students without relying on the school status. This is in line with the statements of the study participants as follows:

“... Indeed, our school is one of the best in exam results ... one reason we get students with a good educational background ... but in fact, it is just a bonus ... not a guarantee that students will get excellent results ... I said like that, the reason is that not all of our students get excellent results ... many are also mediocre ... it means there are still things that need to be improved ... maybe the students themselves need more effort ... and we on the teachers'side need to improve effort ... and find the best formula while teaching .. there may be shortcomings on our part ...

(SK/ PKK 4:24)

“... Our school also has excellent students ... like last year's SPM result, one student got $9 \mathrm{~A}$... only the overall NGP of the school is still low ... our school is not balanced in terms of excellent students and failed students ...

(SH/ PKH 7:50) 
The study's findings show that both categories of schools comply with guidelines set by the Ministry of Education Malaysia in implementing teaching supervision. Overall, it can be concluded that teaching supervision in schools is done by delegating supervision tasks to middle leaders including the school's administrative assistant, senior assistants for student affairs, senior assistant for co-curricular affairs, and field leaders. This approach aims to ensure that all teachers in schools are supervised in teaching as directed by the Ministry of Education Malaysia. In addition, this approach aims to overcome the time constraints and workload faced by principals who are heavily involved in managing administrative affairs in schools.

4.2 What Are the Teaching Supervision Practices Adopted in Excellence Cluster Secondary Schools and Daily Secondary Schools?

Analysis of the study data showed that the category of schools has no specific approach in implementing teaching supervision. Instead, teaching supervision is fully guided by the SKPMG2 teaching supervision form no. 4. In this regard, the clinical supervision approach is seen as an approach that can be used as a teaching supervision practice. This approach comprises five phases of instructional supervision, i) pre-observation conference, ii) observation, iii) analysis, iv) post-observation conference, and v) post-observation conference analysis. However, not all of these phases have been implemented during the teaching supervision process. This situation was explained through statements of study participants as follows:

“... Yes .. we call first .. we will tell the teacher when we want to supervise ... we have to call because we want to see the schedule and want to set a suitable time ..."

(SK/ PKP 2: 15)

“... A detailed discussion before I enter the class is not ... I just call the teacher, ask for a suitable time and time that I can go in to see him teach ..."

(SH/ PKK 8:60)

Teaching supervision is implemented by directly observing the teaching and learning process in the classroom. Supervisors will obtain a timetable and consent from the teacher to evaluate the lessons implemented. The teaching evaluation is based on the criteria stated in the teaching supervision form. The supervisor will sit at the back of the classroom to observe the teaching and learning process. The study participants confirmed this through the following statements:

“... I will ask the teacher's permission to enter the class ... I want to see the PdPc process that takes place in the classroom ... because from there I can only evaluate the extent of the teacher's teaching..."

(SK/ PPH 1: 9)

"... I will sit in the back ... then I can see the whole thing that is happening in the classroom ... moreover, if I sit in the back, it is not very disturbing for the teacher to teach ..." (SH/ PKP 6:43)

The analysis of classroom observation data helps identify teachers' weaknesses and strengths. 


\section{Macrothink}

International Journal of Human Resource Studies

ISSN 2162-3058

2021, Vol. 11, No. 4S

However, the study's findings indicate that not all data obtained by supervisors were analysed as they should be, as stated by the study participants:

"... The analysis in detail is not ... to me .. I saw the data at a glance ... if the teacher's teaching is all ok ... it means there is no problem .. there is no need to do an analysis ..."

(SK/ PKK 4:25)

“... I agree ... the analysis is important ... because through the way we know the teacher's weaknesses ... even if the teacher's teaching is problematic ... overall what I saw when I supervised the teachers' teaching was all ok. .. so there is nothing we want to look for anymore ..."

\section{(SH/ PPH 5:30)}

After making the analysis, the supervisor should conduct a post-observation conference. Supervisors need to work with teachers to discuss the weaknesses and strengths of teachers' teaching that have been detected through the analysis of the data that has been made. The study's findings showed that after the observation, the supervisor' do conduct a discussion session with the teacher; however, the discussion does not focus on the teachers' weaknesses and strengths, as explained by the participants,

“... yes, I had a meeting with the teacher after finishing PdPc ... I had a little speech ... everything went smoothly ... a detailed discussion related to the teaching that the teacher did was not ... I gave a lot of motivation and words of encouragement ..."

(SK/ PKP 2: 17)

"... There is nothing really to be discussed in-depth ... because the teaching is ok ... the students also seem to be able to accept what the teacher conveys ... and all the criteria in the form get high scores ... for me. . So I just congratulated the teacher ..."

(SH/ PKP 6:44)

The final stage in the clinical supervision approach is the post -observational conference analysis. At this stage, the supervisor conducts an in-depth analysis after all four stages have been passed to determine whether there is a need to implement second teaching supervision of the teacher's teaching. Analysis of the interview data and observation data showed no post-observation conference analysis because the supervisor thought that the teaching and learning process implemented by the teachers had met the set curriculum standards. A detailed explanation can be seen through the statements of study participants as follows:

“... If you look at the teachers I supervise, they all score high marks ... it means they have taught well ... so there is nothing to question ..."

(SK/ PKK 4:27)

"... There are weaknesses in teachers ... but we can't put all teachers to be able to teach perfectly ... because there are many factors that we need to take into account ... depending on the supervisor, if he feels the need to supervise again .. ok .. for me if the teacher can implement PdPc as the curriculum should be ... students understand ok la .. a little lack is 
normal la ..."

(SH/ PKH 7:52)

Overall it can be concluded that the clinical supervision approach has not yet been fully implemented in teaching supervision in schools. This is evidenced by only two of the five phases of the clinical supervision approach; specifically, the supervisors implemented the pre-observation and observation sessions. Meanwhile, the other three phases, the analysis, post-observation session and post-observation session analysis, did not occur directly in teaching supervision. Instead, supervisors focus on observation in the classroom and fully evaluate teachers' teaching based on the teaching supervision form.

\section{Discussion, Implementation and Recommendation}

Teaching supervision approaches refer to methods planned by a school to ensure teaching supervision occurs in accordance with MOE professional circular letter no 3/ 1987. The responsibility of supervising teaching in schools is delegated to middle leaders. Time constraints and the workload of school management have limited the ability of principals to assume the responsibility of supervising teaching on their own. This study is consistent with the study conducted by Khairul Effendi, Faiz and Hapini (2019), which showed that senior assistants and field leaders are also involved in supervising teaching in schools. The teaching supervision procedure is guided by the standard SKPMG2 supervision form 4. This study's findings are also aligned with Md Said Daimon (2019). This study showed that some supervisors are less experienced in supervision as some of these supervisors were just appointed as field leaders. The study also observed that both categories of schools practice delegation.

Another significant finding is that the schools do not apply any specific approach for teaching supervision. In this regard, the clinical supervision approach for instructional supervision requires in-depth knowledge and understanding among supervisors. While the clinical supervision approach is appropriate for ensuring that teaching supervision can be implemented effectively, teaching supervision in schools has yet to wholly apply the clinical supervision approach. This discussion is in line with a study already conducted by Acheson \& Gall (2014). The willingness of supervisors to apply such an approach while supervising teaching requires knowledge and skills through direct exposure by the Ministry of Education Malaysia. This is because teaching supervision in schools is largely oriented to evaluate teaching in the classroom entirely based on the prescribed teaching supervision form (Shukri Zain, 2011). Both categories of schools were seen not to make full use of the teaching supervision approach as discussed.

This study has presented a case study on the teaching supervision approach implemented in two different school categories. It was found that there is no difference between the teaching supervision approach applied in Excellence Cluster Secondary Schools and Daily Secondary Schools. Thus, it can be concluded that the form of implementation of teaching supervision and the practice of teaching supervision in both categories of schools are similar. The study showed that despite the high academic achievement in Excellence Cluster Secondary Schools, 
it does not reflect students' overall achievement. Some students in Excellence Cluster Secondary Schools obtained moderate academic achievement and showed the same performance as students in Daily Secondary Schools. The study also found that some students of Daily Secondary Schools have obtained excellent academic results on par with students in Excellence Cluster Secondary Schools. However, the level of excellence in Daily Secondary Schools is still low compared to Excellence Cluster Secondary Schools. This situation shows that students' academic excellence does not only depend on the students' achievement. It is also directly related to teachers' quality of teaching and lesson delivery. Therefore, the administrators at Excellence Cluster Secondary Schools need to strengthen teaching supervision practices to improve the quality of teachers' teaching and ensure students' excellence. This could ensure the growth of academic excellence parallel to students' quality and school status. Overall, there is no difference in the characteristics studied in terms of the method of implementation of teaching supervision in Excellence Cluster Secondary Schools and Daily Secondary Schools.

This study also revealed that middle-level leaders need to improve their skills and knowledge on teaching supervision, especially in determining the appropriate supervisory approaches. In particular, the Ministry of Education needs to formulate a programme for developing middle leaders' competency in implementing teaching supervision in schools. This is because middle leaders are directly involved in supervising teaching through the delegation of authority from the principal. Overall, the study showed that teachers' quality of teaching in both school categories need to be improved and developed continuously to optimise students' acquisition and understanding of the content delivered by teachers. Therefore, teaching supervision practices need to be strengthened by improving supervisors' skills and knowledge on effective implementation of teaching supervision. Moreover, supervisors need to be exposed to more effective instructional supervision approaches such as clinical supervision approaches to ensure the effectiveness of instructional supervision.

\section{Conclusion}

The effectiveness of instructional supervision depends on the role played by principals and middle leaders in the school. Principals as instructional leaders should act effectively by planning and managing programs related to implementing instructional supervision in schools. This is because the stability in school management will guarantee the effectiveness of the teaching supervision process. The Ministry of Education Malaysia needs to study and highlight the appropriate teaching supervision approach in teaching supervision. The procedures and approaches in teaching supervision also need to change in line with the demands of today's education. In this light, the effective implementation of teaching supervision is a mechanism towards improving the quality of teaching and teachers' professionalism.

\section{References}

Acheson, K. A., \& Gall, M. D. (2014). Clinical Supervision and Teacher Development: Preservice and Inservice Applications. (5th ed.). NY: John Wiley \& Sons, Inc. 
Ahmad, K. (2016). Pelaksanaan Amalan Penyeliaan Pengajaran Oleh Kepimpinan Instruksional Dan Hubungannya Dengan Motivasi Kerja Guru Di SMK Harian. Tesis PhD: Universiti Malaya. Kuala Lumpur.

Che, K. E., Mohd, F., \& Hapini (2019). Tahap Dan Perasaan Ketika Penyeliaan Pengajaran Guru: Kajian Di Sekolah Agama Yayasan Islam Kelantan. Journal of Educational Research And Indigenous Studies, 2(1).

Chien-Chin, C. (2018). Facilitation of Teachers' Professional Development Through Principals' Instructional Supervision And Teachers' Knowledge-Management Behaviors. National Chengchi University: Taipei, Taiwan. https://doi.org/10.5772/intechopen.77978

Creswell, J. W. (2020). Educational Research: Planning, Conducting, and Evaluating Quantitative And Qualitative. Research Plus Pearson Mylab Education with Pearson. Pearson.

Douglas, B. R. (2020). The Learning Leader: How to Focus School Improvement for Better Results. ASCD, North Beauregard St. Alexandria. USA.

Holloway, E. (2016). Supervision Essentials for a Systems Approach to Supervision: Clinical supervision essentials series. American Psychological Association. 000

Glickman, P., Gordon, \& Ross-Gordon. (2017). Supervision and Instructional Leadership: A Developmental Approach. Pearson Education.

Kathryn, L., Debbie, F. C., \& Theresa, Y. (2019). Supervision Modules to Support Educators in Collaborative Teaching: Helping to Support \& Maintain Consistent Practice in the Field. Information Age Publishing, Inc. Charlotte, North Carolina.

Kementerian Pendidikan Malaysia. (2012). Penyeliaan Pengajaran dan Pembelajaran Di Dalam Kelas Oleh Pengetua/ Guru Besar. Surat Pekeliling Ikhtisas Bil. 3/ 1987. Putrajaya, Malaysia.

Marja, S. (2017). Case Study Strategies for Architects and Designers: Integrative Data Research Methods. Taylor \& Francis Group. New York and London.

Md Said, D. (2019). Alat Pengurusan Sekolah. Ringkasan SKPMG2 Standard Kualiti Pendidikan Malaysia Gelombang 2. Kementerian Pendidikan Malaysia.

Meredith, I. H., \& Lydia, R. R. (2020). Supervising Principals for Instructional Leadership: A Teaching and Learning Approach. Cambridge, Massachusetts. Harvard Education Press.

Mohammed Sani (2013). Peranan Guru Kanan Mata Pelajaran Dalam Mempertingkatkan Kualiti Pengajaran Guru. Jurnal Kurikulum \& Pengajaran Asia Pasifik, 1(1), 28-41.

Monique, H, Inge, H., \& Ajay, B. (2020). Qualitative Research Methods. SAGE Publications. Shukri, Z. (2011). Penyeliaan Pendidikan: Teori dan amalan. Tanjung Malim:Emeritus Publications.

Gordon, S. (2020). Standards for Instructional Supervision: Enhancing Teaching and 


\section{Macrothink}

International Journal of Human Resource Studies

ISSN 2162-3058 2021, Vol. 11, No. 4S

Learning. Routledge, Taylor \& Francis Group. New York. https://doi.org/10.4324/9781315855301

Zabidah, A., \& Mohd, Z. I. (2019). Amalan Kepimpinan Instruksional. UKM Press. Universiti Kebangsaan Malaysia.

\section{Copyright Disclaimer}

Copyright for this article is retained by the author(s), with first publication rights granted to the journal.

This is an open-access article distributed under the terms and conditions of the Creative Commons Attribution license (http://creativecommons.org/licenses/by/4.0/). 